\title{
PENTINGNYA PENCEGAHAN BAHAYA DAN ADVERSE EVENT SEBAGAI UPAYA MENJAGA KESELAMATAN PASIEN DI RUMAH SAKIT
}

\author{
Awina Milla Shilmy Sitorus \\ awinashilmy@gmail.com
}

\section{Latar Belakang}

Rumah sakit adalah sarana pelayanan kesehatan yang dibutuhkan ketika seseorang sakit dan membutuhkan bantuan dengan tujuan untuk menyelamatkan kondisi pasien. Keselamatan Pasien (patient safety) merupakan sesuatu yang jauh lebih penting dari pada sekedar efisiensi pelayanan. Perilaku perawat dengan kemampuan perawat sangat berperan penting dalam pelaksanaan keselamatan pasien. Perilaku yang tidak aman, lupa, kurangnya perhatian/motivasi, kecerobohan, tidak teliti dan kemampuan yang tidak memedulikan dan menjaga keselamatan pasien berisiko untuk terjadinya kesalahan dan akan mengakibatkan cedera pada pasien, berupa Near Miss (Kejadian Nyaris Cedera/KNC) atau Adverse Event (Kejadian Tidak Diharapkan/KTD) selanjutnya pengurangan kesalahan dapat dicapai dengan memodifikasi perilaku. Perawat harus melibatkan kognitif, afektif dan tindakan yang mengutamakan keselamatan pasien (Julia, 2016).

Cahyono (2008) menyatakan setiap asuhan klinis baik terkait dengan proses diagnosis, terapi, tindakan pembedahan, pemberian obat, pemeriksaan laboratorium, dsb dapat menimbulkan kerugian yang tidak diharapkan pasien baik secara fisik (cedera iatrogenik), finansial, maupun sosial. Secara lebih populer, asuhan klinis yang kemudian menimbulkan dampak yang merugikan bagi pasien akibat manajemen medis dan bukan akibat penyakit yang diderita pasien dikenal sebagai adverse events atau KTD (baik oleh dokter maupun pasien).

Teori Reason menyatakan bahwa insiden keselamatan pasien disebabkan oleh dua faktor, kesalahan laten dan kesalahan aktif. Kesalahan laten terkait dengan insiden keselamatan pasien meliputi lingkungan eksternal, manajemen, lingkungan sosial atau organisasi, lingkungan fisik, interaksi antara manusia dan sistem. Budaya keselamatan adalah bagian dari kesalahan laten yang terkait dengan manajemen, sedangkan indikator budaya keselamatan meliputi kerja sama, komunikasi, kepemimpinan, pelaporan dan respons terhadap kesalahan tidak menghukum. Kunci pencegahan cedera dalam pelayanan keperawatan adalah identifikasi risiko. Hal ini 
sangat tergantung pada budaya kepercayaan, kejujuran, integritas, dan keterbukaan berkomunikasi dalam sistem asuhan keperawatan.

Menurut Ottosen (2015), orang tua ingin terlibat sebagai partner dalam meningkatkan keselamatan anak di rumah sakit. Bagi orang tua, partnership antara tenaga kesehatan dan orang tua penting untuk meningkatkan perannya dalam keselamatan pasien. Orang tua memahami bahwa mereka harus berbagi peran dalam melindungi anak dan meningkatkan keselamatan mereka. Orang tua mengasumsikan perannya dalam keselamatan pasien adalah sebagai pembelajar (Learner), pemberi pelayanan (Caregivers), advocates, pembuat keputusan (Decision-makers) dan sebagai penjaga (Guardian). Peran-peran ini dipengaruhi oleh tingkat pengetahuan dan persepsi orang tua tentang keselamatan pasien, sikap terhadap peran orang tua, komunikasi, teamwork, masalah orang tua dan perubahan perawatan. Wegner \& Pedro (2012), menyebutkan bahwa peran orang tua dalam keselamatan anak di rumah sakit adalah dengan berbagi perawatan dengan tenaga kesehatan berupa memberikan kebersihan dan kenyamanan pada anak dengan tetap dalam supervisi dan arahan dari tenaga kesehatan. Pelibatan pasien dan keluarga dalam meningkatkan keselamatan pasien dipengaruhi oleh otonomi, kesadaran, dan pengetahuan (Buetow et al, 2013). Pasien dan keluarga yang memiliki pengetahuan tentang keselamatan dapat mengedukasi diri mereka sendiri untuk mampu mencegah adanya kejadian yang tidak diharapkan sekaligus mendeteksi kesalahan yang terjadi selama pemberian pelayanan kesehatan di rumah sakit baik dalam persiapan, monitoring maupun follow-up suatu tindakan (Longtin et al, 2010).

\section{Metode}

Metode yang digunakan dalam penulisan ini adalah metode kualitatif yang dimana penulis mengumpulkan data sebanyak-banyaknya untuk dianalisis. Tulisan ini didasarkan dengan menganalisis berbagai jurnal atau karya tulis ilmiah yang berfokus pada "Pentingnya Pencegahan Bahaya dan Adverse Event Sebagai Upaya Menjaga Keselamatan Pasien di Rumah Sakit”. Adapun tinjauan literatur yang digunakan dalam penulisan ini adalah buku teks, jurnal atau karya tulis ilmiah yang berasal dari E-book atau Google Scholar dengan syarat literatur yang digunakan terbitan 10 tahun terakhir. Metode dari penulisan ini dilakukan untuk menjelaskan bagaimana pentingnya mencegah bahaya dan adverse event (Kejadian Tidak Diinginkan) sebagai upaya menjaga keselamatan pasien di Rumah Sakit melalui analisa materi yang dikumpulkan dari sumber buku teks, jurnal atau karya tulis ilmiah. Penulisan ini dilakukan menggunakan metode kajian bebas terhadap pokok bahasan yang dikumpulkan dari 
beberapa sumber yang berkaitan dengan pokok bahasan. Pengolahan ini dilakukan dengan metode membandingkan 10 jurnal atau karya tulis ilmiah yang digunakan dan berhubungan dengan pencegahan bahaya dan adverse event sebagai upaya menjaga keselamatan pasien di Rumah Sakit.

\section{Hasil}

Hasil dari pengkajian menggunakan metode penulisan kualitatif adalah menghasilkan suatu pembelajaran bagaimana upaya mencegah bahaya dan adverse event sebagai upaya menjaga keselamatan pasien di Rumah Sakit yang perlu diterapkan oleh seluruh tenaga kesehatan baik dokter maupun perawat melalui pengumpulan data berdasarkan buku teks, jurnal atau karya tulis ilmiah. Adapun sembilan solusi keselamatan pasien (nine saving safety Solution), yaitu :

1. Perhatikan Nama Obat, Rupa dan Ucapan Mirip (Look-Alike, Sound-Alike Medication Names).

2. Pastikan Identifikasi Pasien.

3. Komunikasi Secara Benar saat Serah Terima / Pengoperan Pasien.

4. Pastikan Tindakan yang benar pada Sisi Tubuh yang benar.

5. Kendalikan Cairan Elektrolit Pekat (Concentrated).

6. Pastikan Akurasi Pemberian Obat pada Pengalihan Pelayanan.

7. Hindari Salah Kateter dan Salah Sambung Slang (Tube).

8. Gunakan Alat Injeksi Sekali Pakai.

9. Tingkatkan Kebersihan Tangan (Hand Hygiene) untuk Pencegahan infeksi Nosokomial.

Selain itu, terdapat tujuh Langkah Menuju Keselamatan Pasien, yaitu :

1. Membangun kesadaran akan nilai Keselamatan Pasien.

Ciptakan budaya adil dan terbuka

2. Memimpin dan mendukung staf.

Tegakkan fokus yang kuat dan jelas tentang keselamatan pasien di seluruh Fasilitas pelayanan Kesehatan Anda.

3. Mengintegrasikan aktivitas pengelolaan risiko.

Bangun sistem dan proses untuk mengelola risiko dan mengidentifikasi kemungkinan terjadinya kesalahan.

4. Mengembangkan sistem pelaporan. 
Pastikan staf Anda mudah untuk melaporkan insiden secara internal (lokal) maupun eksternal (nasional).

5. Melibatkan dan berkomunikasi dengan pasien.

Kembangkan cara-cara berkomunikasi secara terbuka dan mendengarkan pasien.

6. Belajar dan berbagi pengalaman tentang Keselamatan Pasien.

Dorong staf untuk menggunakan analisa akar masalah guna pembelajaran tentang bagaimana dan mengapa terjadi insiden.

7. Mencegah cedera melalui implementasi sistem Keselamatan Pasien Pembelajaran lewat perubahan-perubahan di dalam praktik, proses atau sistem. Untuk sistem yang sangat kompleks seperti Fasilitas pelayanan Kesehatan untuk mencapai hal-hal diatas dibutuhkan perubahan budaya dan komitmen yang tinggi bagi seluruh staf dalam waktu yang cukup lama.

\section{Pembahasan}

Keselamatan pasien di Rumah Sakit adalah sistem pelayanan dalam suatu Rumah Sakit yang memberikan asuhan pasien menjadi lebih aman, termasuk di dalamnya mengukur risiko, identifikasi dan pengelolaan risiko terhadap pasien, analisa insiden, kemampuan untuk belajar dan menindaklanjuti insiden serta menerapkan solusi untuk mengurangi risiko. Keselamatan pasien merupakan suatu sistem yang sangat dibutuhkan mengingat saat ini banyak pasien yang dalam penanganannya sangat memprihatinkan, dengan adanya sistem ini diharapkan dapat meminimalisir kesalahan dalam penanganan pasien baik pada pasien UGD, rawat inap maupun pada pasien poliklinik.

Segala upaya yang dilakukan oleh pihak rumah sakit merupakan bentuk komitmen rumah sakit untuk terus memperbaiki diri. Upaya tersebut dilakukan agar tidak terjadi kejadian yang tidak diinginkan dan terbebas dari kesalahan sehingga tidak berdampak bagi pasien. Menurut Komite Keselamatan Pasien Rumah Sakit (2008) salah satu langkah menuju keselamatan pasien yaitu membangun komitmen yang kuat tentang keselamatan pasien dengan memasukkan keselamatan pasien sebagai agenda kerja. Komitmen rumah sakit tentang peningkatan keselamatan pasien merupakan kunci penting terwujudnya keselamatan bagi pasien dan terhindar dari KTD.

Dalam upaya membangun keselamatan pasien memerlukan komitmen yang di pengaruhi oleh pengetahuan perawat. Perawat yang memiliki pengetahuan yang baik akan keselamatan pasien pastinya memiliki sikap yang baik dalam meningkatkan mutu dalam pelayanan kesehatan, hal 
ini sesuai dengan pendapat Majid (2011) yang mengemukakan bahwa pengetahuan merupakan pangkal dari sikap, sedangkan sikap akan mengarah pada tindakan seseorang. Pengetahuan merupakan hasil tahu dan ini terjadi setelah seseorang melakukan pengindraan terhadap suatu objek tertentu. Pengetahuan ini merupakan hal yang dominan yang sangat penting untuk terbentuknya tindakan seseorang, dari pengalaman beberapa penelitian ternyata tindakan yang tidak didasari pengetahuan yang baik, tidak akan menghasilkan hasil yang baik (Notoadmojo, 2010). Terdapat 5 indikator sebagai upaya menjaga keselamatan pasien, yaitu :

\section{Kerja sama}

Kerja sama merupakan indikator pertama dari budaya keselamatan pasien. Dalam melaksanakan asuhan keperawatan kepada pasien perawat akan selalu membutuhkan bantuan dari perawat maupun tenaga kesehatan yang lainnya. Bentuk kerja sama tidak hanya berupa saling membantu pekerjaan ketika perawat dihadapkan pada tugas yang sangat banyak dan membutuhkan penyelesaian yang sesegera mungkin, namun juga bisa berupa pembagian tugas berdasarkan kelompok kecil atau tim dalam satu unit ruang rawat inap. Perawat adalah petugas kesehatan dengan waktu kerja tertinggi yang memberikan 24 jam pelayanan terus menerus, melakukan kolaborasi dengan tim kesehatan lain dan oleh karena hal tersebut dapat menyebabkan risiko terjadinya cedera. Keterlibatan banyak profesi selain tenaga perawat dalam melakukan asuhan keperawatan dapat menimbulkan atau berisiko terjadi cedera jika dilakukan tidak dengan komunikasi dan koordinasi yang tepat, hal itu (cedera) dapat dihindari jika perawat selalu menjaga hubungan baik dengan sesama perawat dan petugas kesehatan lainnya, dan menjaga keharmonisan di lingkungan kerja atau suasana hati untuk mencapai pelayanan kesehatan.

\section{Komunikasi}

Komunikasi sangatlah penting dalam setiap melaksanakan tugas dalam hal ini adalah melaksanakan asuhan keperawatan pada pasien. Komunikasi yang baik dan benar perlu dilakukan untuk mengkoordinasikan asuhan keperawatan yang melibatkan banyak profesi selain profesi perawat. Komunikasi dalam praktik keperawatan merupakan elemen penting bagi perawat dalam melaksanakan asuhan keperawatan untuk mendapatkan hasil yang optimal. Perawat memiliki peran yang paling dominan dalam mencegah terjadinya kesalahan dalam pengobatan, termasuk pelaporan insiden, mendidik diri sendiri dan perawat lain tentang penting komunikasi, memberikan rekomendasi untuk perubahan prosedur dan kebijakan serta keterlibatan dalam melakukan identifikasi permasalahan. Kesalahan medis jarang disebabkan 
oleh faktor kesalahan manusia secara individual, tetapi lebih karena kesalahan pada sistem komunikasi yang menyebabkan terputusnya rantai dalam sistem tersebut. Hal ini menunjukkan pentingnya menjalin komunikasi dengan baik agar informasi yang disampaikan tidak terputus dan mengakibatkan kerugian pada pasien. Sistem dan interaksi manusia mengacu pada sistem dimana dua sistem berinteraksi atau berkomunikasi dalam ruang lingkup sistem tersebut. Informasi tentang keselamatan pasien perlu diketahui oleh semua perawat yang memberikan asuhan keperawatan hal tersebut berfungsi untuk mencegah perawat melakukan tindakan yang dapat menyebabkan cedera pada pasien. Komunikasi adalah kunci sukses berinteraksi dalam kehidupan berorganisasi. Ketika komunikasi efektif, arus informasi dalam organisasi yang dinamis akan berjalan lancar sehingga mempercepat proses tercapainya tujuan organisasi.

\section{Kepemimpinan}

Pemimpin harus memiliki komitmen yang kuat terhadap keselamatan pasien, sehingga keselamatan pasien menjadi hal yang utama dalam memberikan pelayanan keperawatan. Pemimpin harus mampu menjadi agen perubahan bagi anak buahnya dengan melaksanakan program keselamatan pasien. Pimpinan mendorong dan menjamin implementasi program keselamatan pasien secara terintegrasi dalam organisasi melalui penerapan "Tujuh Langkah Menuju Keselamatan Pasien Rumah Sakit”. Pemimpin harus membangun komitmen dan fokus yang kuat dan jelas guna mendukung staf untuk menjalankan program keselamatan pasien secara berkesinambungan, memprioritaskan atau mengintegrasikan program keselamatan pasien dalam setiap rapat dengan para pengambil keputusan, mengagendakan pelatihan tentang keselamatan pasien bagi semua staf secara berkala dan berkesinambungan. Pimpinan menjamin berlangsungnya program proaktif untuk identifikasi risiko keselamatan pasien dan program menekan atau mengurangi Kejadian Tidak Diharapkan. Pimpinan mendorong dan menumbuhkan komunikasi dan koordinasi antar unit dan individu berkaitan dengan pengambilan keputusan tentang keselamatan pasien. Pimpinan mengalokasikan sumber daya yang adekuat untuk mengukur, mengkaji, dan meningkatkan kinerja rumah sakit serta meningkatkan keselamatan pasien. Pimpinan mengukur dan mengkaji efektivitas kontribusinya dalam meningkatkan kinerja rumah sakit dan keselamatan pasien. Pada unit kerja berikan semangat kepada rekan kerja untuk secara aktif melaporkan setiap insiden yang terjadi dan insiden yang telah dicegah tetapi tetap terjadi juga, karena mengandung bahan pelajaran yang penting. Pemimpin harus mampu memotivasi bawahannya, salah satunya dengan pujian. Pujian yang diberikan oleh pemberi kerja pada saat pekerjaan yang selesai dilakukan sesuai dengan prosedur yang ditetapkan akan memberikan motivasi tersendiri untuk perawat. 


\section{Pelaporan}

Indikator pelaporan dalam penerapan budaya keselamatan pasien berada dalam kategori cukup. Perawat diharuskan melaporkan kejadian kesalahan yang tidak disengaja dan kondisi yang mengakibatkan atau berpotensi mengakibatkan cedera yang dapat dicegah pada pasien, yang terdiri dari kejadian tidak diharapkan, kejadian nyaris cedera, kejadian tidak cedera dan kejadian potensial cedera. Melaporkan sebuah kejadian atau insiden keselamatan pasien masih jarang dilakukan atau pun bahkan jika ada pelaporan tentang insiden atau kejadian keselamatan pasien belum ada pelaporan secara resmi. Hal ini disebabkan para perawat takut untuk melaporkan insiden yang terjadi pada pasien karena kesalahan yang dilakukannya. Perawat merasa takut akan hukuman dari penyelia atas kesalahan yang telah ia lakukan saat melakukan asuhan keperawatan. Sejatinya pelaporan insiden keselamatan pasien sangat dibutuhkan oleh semua pihak guna perbaikan pelayanan dalam hal ini khususnya asuhan keperawatan. Informasi dari pelaporan insiden keselamatan pasien yang akurat dan jelas dapat membantu identifikasi akar permasalahan bagaimana insiden tersebut bisa terjadi serta identifikasi faktor risiko sehingga insiden yang sama dapat dicegah untuk kemudian hari. Peran dan fungsi perawat yang salah satunya yaitu peran sebagai peneliti. Informasi yang benar dan jelas yang diperoleh dai sistem pelaporan, asesmen risiko, kajian insiden, dan audit serta analisis, digunakan untuk menentukan solusi.

\section{Respon Tidak Menghukum}

Terhadap Kesalahan Indikator respons tidak menghukum terhadap kesalahan ini menunjukkan bahwa dimasa yang akan datang pelaporan terhadap insiden keselamatan pasien tidak sematamata hanya berupa pelaporan insiden keselamatan, namun pelaporan tersebut hendaknya ditindaklanjuti guna memperbaiki kesalahan dan mencari akar permasalahan, tidak untuk menghukum perawat yang melakukan kesalahan atau berpengaruh terhadap penilaian kinerjanya. Ketika kesalahan dilaporkan, maka cukup melaporkan masalah sendiri dilaporkan menemukan jalan keluar tidak menunjukkan siapa pelaku harus dihukum. Belajar dari insiden keselamatan pasien hanya akan berhasil jika setiap permasalahan tidak dilihat sebagai kesalahan individu tetapi harus diperhatikan dengan pendekatan sistem dan pemahaman faktor manusia. Sebagaimana diatur dalam Peraturan Menteri Kesehatan Republik Indonesia nomor 755/Menkes/Per/IV/2011 tentang pelaksanaan komite medis di rumah sakit bahwa audit medis dilakukan dengan memprioritaskan semua staf untuk menghilangkan blamming (menyalahkan), naming (menyebut atau mencari siapa yang salah), dan shaming 
(mempermalukan atau mengakui kesalahan). Untuk mampu belajar dari kesalahan harus ditekankan pada upaya mencari apa yang salah, mengapa kesalahan tersebut dapat terjadi, dan apa yang bisa dilakukan untuk memperbaiki kesalahan.

\section{Penutup}

\section{Kesimpulan}

Keselamatan pasien di Rumah Sakit adalah sistem pelayanan dalam suatu Rumah Sakit yang memberikan asuhan pasien menjadi lebih aman, termasuk di dalamnya mengukur risiko, identifikasi dan pengelolaan risiko terhadap pasien, analisa insiden, kemampuan untuk belajar dan menindaklanjuti insiden serta menerapkan solusi untuk mengurangi risiko. Keselamatan pasien merupakan suatu sistem yang sangat dibutuhkan mengingat saat ini banyak pasien yang dalam penanganannya sangat memprihatinkan, dengan adanya sistem ini diharapkan dapat meminimalisir kesalahan dalam penanganan pasien baik pada pasien UGD, rawat inap maupun pada pasien poliklinik. Komitmen rumah sakit tentang peningkatan keselamatan pasien merupakan kunci penting terwujudnya keselamatan bagi pasien dan terhindar dari KTD. Terdapat 5 indikator sebagai upaya menjaga keselamatan pasien, yaitu kerja sama, komunikasi, kepemimpinan, pelaporan dan respon tidak menghukum.

\section{Referensi}

Aini, S. N. \& Sudaryanto. (2018). Gambaran Pengetahuan Orang Tua Tentang Speak Up Keselamatan Pasien dan Penerapannya di RSUP Dr. Sardjito Yogyakarta. Jurnal Keperawatan CARE, Vol. 8, No.1.

Aini, S. N. \& Wiraswati, K. A. (2018). Validitas dan Reliabilitas Instrumen Pengetahuan Orang Tua Tentang Speak Up Keselamatan Pasien. Jurnal Keperawatan CARE, Vol. 8, No.1.

Fitriana, Y. \& Pratiwi, K. (2018). Pelaksanaan Patient Safety di Rumah Sakit Umum Daerah dan Rumah Sakit Umum Swasta Bantul Berdasarkan Ketentuan Undang-Undang Nomor 44 Tahun 2009 Tentang Rumah Sakit. Jurnal Kebidanan, Volume 7, Nomor 1.

Futriani, E. S. (2018). Hubungan Pengetahuan dan Sikap Dengan Penerapan Standar Keselamatan Pasien Di Instalasi Perawatan Intensif. Jurnal Antara Keperawatan, Vol. 1, No. 1.

Herawati, Y. T. (2015). Budaya Keselamatan Pasien di Ruang Rawat Inap Rumah Sakit X Kabupaten Jember. Jurnal IKESMA, Volume 11, Nomor 1. 
Lambogia, A., dkk. (2016). Hubungan Perilaku Dengan Kemampuan Perawat Dalam Melaksanakan Keselamatan Pasien (Patient Safety) di Ruang Akut Instalasi Gawat Darurat RSUP Prof. Dr. R. D. Kandou Manado. e-journal Keperawatan (e-Kp), Volume 4, Nomor 2.

Nivalinda, D., dkk. (2013). Pengaruh Motivasi Perawat dan Gaya Kepemimpinan Kepala Ruang Terhadap Penerapan Budaya Keselamatan Pasien Oleh Perawat Pelaksana Pada Rumah Sakit Pemerintah di Semarang. Jurnal Managemen Keperawatan, Volume 1, No. 2.

Simamora, R. H. (2019). Pengaruh Penyuluhan Identifikasi Pasien Dengan Menggunakan Media Audiovisual Terhadap Pengetahuan Pasien Rawat Inap, Jurnal Keperawatan Silampari, Volume 3, Nomor 1.

Simamora, R. H. (2019). Buku ajar pelaksanaan identifikasi pasien. Uwais Inspirasi Indonesia. Suparti, Sri. (2018). Pengaruh Penyampaian Pasien Safety terhadap Pengetahuan Mahasiswa Keperawatan Universitas Muhammadiyah Purwokerto. SAINTEKS, Volume 15, Nomor 2.

Triwibowo, C., dkk. (2016). Studi Kualitatif : Peran Handover Dalam Meningkatkan Keselamatan Pasien di Rumah Sakit. JURNAL PENA MEDIKA, Vol. 6, No. 2. 